\title{
Use of Slowmation in Biology Teaching
}

\author{
Ferit Karakoyun $^{1} \&$ İ. Ümit Yapıc1 ${ }^{2}$ \\ ${ }^{1}$ Department of Computer Education and Instructional Technology, Dicle University, Diyarbakır, Turkey \\ ${ }^{2}$ Department of Biology Education, Dicle University, Diyarbakır, Turkey \\ Correspondence: Ferit Karakoyun, Department of Computer Education and Instructional Technology, Dicle \\ University, Diyarbakır, Turkey. Tel: 90-505-670-5184. E-mail: ferit.karakoyun@dicle.edu.tr
}

Received: June 4, $2018 \quad$ Accepted: July 13, $2018 \quad$ Online Published: September 27, 2018

doi:10.5539/ies.v11n10p16 URL: https://doi.org/10.5539/ies.v11n10p16

\begin{abstract}
The purpose of the study was to investigate the views of preservice teachers about use of slowmation in biology teaching. In the study, descriptive model was used. The participants were 12 third-grade preservice teachers in the department of Biology Education at Ziya Gökalp Education Faculty of Dicle University in the Spring Term of the academic year of 2016-2017. The research data were collected via observations and semi-structured interviews. In the research process slowmation activities were carried out with preservice biology teachers and at the end of these activities the preservice teachers' views about the activities were determined. The data collected in the study were analyzed using the content analysis method. As revealed by the analysis of the data, the preservice teachers thought that the slowmation activities contributed to the development of some 21 st century skills such as creativity, communication and cooperation skills, information literacy, research skills, technology and media literacy skills. In addition, the preservice teachers reported that the process of creating slowmation was interesting and that they entertained in the process. On the other hand, the preservice teachers also stated that it was difficult to create scenarios and that they experienced problems with the materials used. Moreover, it was seen that the preservice teachers faced problems with the video editing software and that they experienced disputes regarding the distribution of duties during group works. The preservice teachers also put forward suggestions regarding the use of slowmation activities in biology teaching saying that teachers and students could work together in the application process; that activities could be carried out to summarize the subject and to increase permanency; and that different tools and software programs could be used.
\end{abstract}

Keywords: slowmation, animation, biology teaching, preservice teachers

\section{Introduction}

The rapid changes experienced in 21 st century Information and Communication Technologies (ICT) have brought about changes in the society as well as in educational institutions that direct these societies. With the developing technology, information is produced and spread rapidly and made accessible to large populations (Atalay, 2015).

Individuals are supposed to have higher order skills besides other basic skills to adapt themselves to these changes, to select, analyze and evaluate the information among piles of rapidly-produced information, to use the information in their daily lives and to transform the information into product. All these skills that individuals should have in an information society are called 21st century skills (Anagün, Atalay, Kiliç, \& Yaşar, 2016).

Partnership for 21st Century Learning (P21), which was established to make students prepared for the 21st century, defines 21 st century skills as the combination of literacies, specializations, special skills and contents necessary for students to become successful in their social and school lives (Paige, 2009). P21 classifies 21st century skills as learning and innovation skills, life and career skills and information, media and technology skills. According to P21, the skills individuals use in the learning process are handled under the heading of "Learning and Innovation Skills"; the skills they use and develop in life under the heading of "Life and Career Skills"; and the skills involving technology are handled under the heading of "Information, Media, and Technology Skills" (Atalay, 2015). Besides P21, corporations like OECD (Organization for Economic Co-operation and Development), ISTE (International Society for Technology in Education) and ATCS (Assessment and Teaching of 21st Century Skills) also classified the 21 st century skills. Though these skills have been classified in different ways, all these classifications have some common features. In 21 st century skills, the emphasis is on creativity, critical thinking, working cooperatively and problem solving. 21st century skills cover reaching and using the information, 
respecting different cultures and living together with different cultures. In 21 st century skills, being an active citizen is more important than being a good citizen. Individuals with these skills continue their lives in a more productive and qualified manner (Anagün et al., 2016).

Education environments should be organized in a way to develop 21st century skills for the purpose of meeting the demands of the society and of the global economy (CEO Forum on Education and Technology, 2001). In this respect, besides being regarded as a teaching tool for teachers, education technologies could also act as a valuable tool to develop students' 21st century skills (Partnerships for 21st Century Learning, 2009). Among the most popular types of education technologies are animations.

Animation refers to moving a number of images or graphs within the framework of a certain scenario (Çelik, 2007). Animations are created through a connection established between sequenced visuals. Animations used in many areas are favored especially for teaching complex concepts (Genç, 2014). It is important to concretize and visualize abstract concepts so that students can learn easily. In order to visualize the content presented in class, computer animations have an important place especially in science teaching. For meaningful learning, the contents presented to students should be coded both verbally and visually, and they are supposed to re-structure these contents in their minds. Meaningful learning facilitates not only storing the information but also recalling it from the memory (Sezgin, 2002). The fact that abstract concepts are abundant in science courses and that a teaching method involving the use of animations for teaching these abstract concepts is more successful than traditional method of teaching demonstrate that animations contribute positively to education (İnaç, 2010). Due to the broad content, often abstract and dynamic nature of the biology lessons, effective teaching can be done with animations (Yakışan, Yel, \& Mutlu, 2013). According to Sanger, Brecheisen and Hynek (2001), the use of computer animations in teaching helps students to understand abstract molecular biology concepts such as diffusion, osmosis, active transport, three-dimensional structure of DNA, cellular transport system, membrane structure and enzyme-substrate complex. Yakışan (2008) reached the conclusion in his work that biology education which was enriched with animations was effective in eliminating the misconceptions of students.

Despite all these advantages, preparing an animation is a difficult process. The fact that it is easier to prepare and that it can be prepared even by students has led to frequent use of a new animation technique called slowmation.

\subsection{Slowmation}

"Slowmation" is a concept created with the combination of the words "slow" and "animation". This technique involved taking the photos of hand-made materials and gathering them on a computer screen. When each photo frame is put one after another, the photos look as if they were moving (Hoban, 2005).

The most important feature of slowmation is that it includes 2 frames a second rather than 24 frames a second like the computer animation. The reason is that the purpose is not to present a story but to show and explain a scientific concept (Hoban, 2007). In this respect, the purpose of slowmation applications is to create an animation by having students think about the concepts and put forward visuals regarding how they perceive the concepts (Atalay, 2015).

In the process of preparing a slowmation, first of all, the teacher gives information to students about basic concepts. Following this, students conduct research on the subject about which will create slowmation, and they then create a scenario based on the information they have obtained. In the next stage, materials appropriate to the scenario are designed. These materials could be two- or three-dimensional materials made up of plastic, play dough, card or papers. Afterwards, photos of the materials prepared are taken in the order appropriate to the subject. After the process of taking photos, they are combined in a way to have two frames in a second with the help of Windows Movie Maker or another similar software program. Lastly, the content could be enriched with music, effects or writings (Hoban \& Nielsen, 2010; Vratulis, Clarke, Hoban, \& Erickson, 2011).

In related literature, it is reported that the slowmation technique makes it easier to prepare animations, makes students active in the learning process and increases students' motivation for learning and that the technique is appropriate to teaching science concepts at all education levels. In addition, the technique has several advantages such as being interesting and entertaining and developing creativity and social interaction. Though it has advantages, it also brings about several disadvantages: it has a high cost; it takes a long time to prepare; it is difficult to apply in crowded classrooms; and it leads to wrong learning if the related research is not done well (E. Ekici \& F. Ekici, 2011, Herrington, Hoban, \& Reid, 2009; Hoban, 2005, 2007; Hoban \& Ferry, 2006; Hoban, Macdonald, Ferry, \& Hoban, 2009; Macdonald \& Hoban, 2009)

It is believed that since the slowmation technique not only allows students to explain scientific concepts easily by making a story using images and models but also facilitates structuring the process of creating an animation, use of this technique in science education may be a better choice when compared to computer animations (Hoban, 2005). 
In addition, slowmations are suggested as a practical activity for teachers who make use of the advantages of information technologies in science education and who aim to facilitate students' learning with the help of the student-centered approach (E. Ekici \& F. Ekici, 2011). In the studies investigating the influence of slowmations on the teaching-learning process, it is reported that these animations contribute to the development of students' 21 st century skills and help them develop positive attitudes towards courses. Also, it was found that the slowmation technique facilitates teaching science concepts and develops conceptual skills (Brown, 2011; Ochsner, 2010).

Since the birth of this technique, more than 400 slowmations have been prepared by preservice teachers in relation to a number of science subjects (day and night formation, phases of the moon, life cycles of various living beings, movements of pieces, magnets, fertilization in plants, movements of plants, water cycle, simple machines, mitotic division, phagocytosis and so on) (Hoban, 2009). When the related literature is reviewed, it is seen that there is no research on the application of slowmations in biology teaching with preservice biology teachers in Turkey (E. Ekici \& F. Ekici, 2011; E. Ekici \& F. Ekici, 2014; Uzun \& Karaman, 2015). Therefore, the present study is believed to contribute to the related literature in this field. In this respect, the present study aimed to examine views of preservice teachers about the use of slowmation activities in biology teaching. For this purpose, the following research questions were directed in the study:

1) What are preservice biology teachers' views about the influence of slowmation activities on the development of 21 st century skills?

2) What are preservice biology teachers' views about the positive aspects of slowmation activities?

3) What are preservice biology teachers' views about the limitations of slowmation activities?

4) What are preservice biology teachers' suggestions regarding slowmation activities?

\section{Method}

In the present study, the descriptive model was used (Creswell, 2013). In the study, qualitative research methods were used in the process of collecting, analyzing and evaluating the research data.

\subsection{Participants}

The participants in the study were 12 third-grade preservice teachers taking the course of Instructional Technologies and Material Design in the department of Biology Education at Ziya Gökalp Education Faculty of Dicle University in the Spring Term of the academic year of 2016-2017. While determining the participants, the purposeful sampling method was used in line with the research purposes (Yıldırım \& Şimşek, 2013).

\subsection{Data Collection Tools}

The research data were collected via researchers' observations and semi-structured interviews. Throughout the application process, the researchers provided the preservice teachers with guidance. At the end of the application process, semi-structured interviews were held with a volunteering student from each of the six groups. The interview form prepared in line with the review of the related literature was made up of six questions in relation to the influence of slowmation activities on the development of the preservice teachers' 21 st century skills, other positive aspects of these activities, limitations and difficulties experienced, and suggestions regarding the use of slowmation activities in biology teaching.

In the interview form, the questions related to 21 st century skills were prepared based on the structure determined by the organization of " 21 st Century Learning Partnership" (Partnerships for 21 st Century Learning, 2009). This structure included the skills related to "learning and innovation", "information, media and technology" and "life and career". Before the interviews, the preservice teachers were informed by the researcher about the 21 st century skills found in the interview form. During the interviews, the researcher asked the preservice teachers to state which of their skills the slowmation activities contributed to and why.

\subsection{Application Process}

The application was carried out in four hours a week for three weeks with 12 third grade preservice teachers taking the course of Instructional Technologies and Material Design in the department of Biology Education in the Spring Term of the academic year of 2016-2017.

In the first week, the preservice teachers were informed about the process of creating slowmation, the use of "Stopmotion Studio" which is a mobile video-editing software program. Following this, the preservice teachers were divided into six groups of two preservice teachers in each, and each group determined the biology subjects that they thought were appropriate for making a slowmation. In the following two weeks, the preservice teachers were asked to follow the process of creating slowmation: 
Background: In this phase, the first step of the process of creating slowmation, the preservice teachers searched the Internet, books and other related information sources and tried to get information about the subjects that they would create slowmation about.

Storyboard: In this phase, the preservice teachers formed drafts with images regarding the animations they would create, and they created scenarios related to the subjects and drew pictures in relation to these scenarios. Each part of a scenario was put in order in templates given by the researchers in a way to create a story in accordance with the drawings.

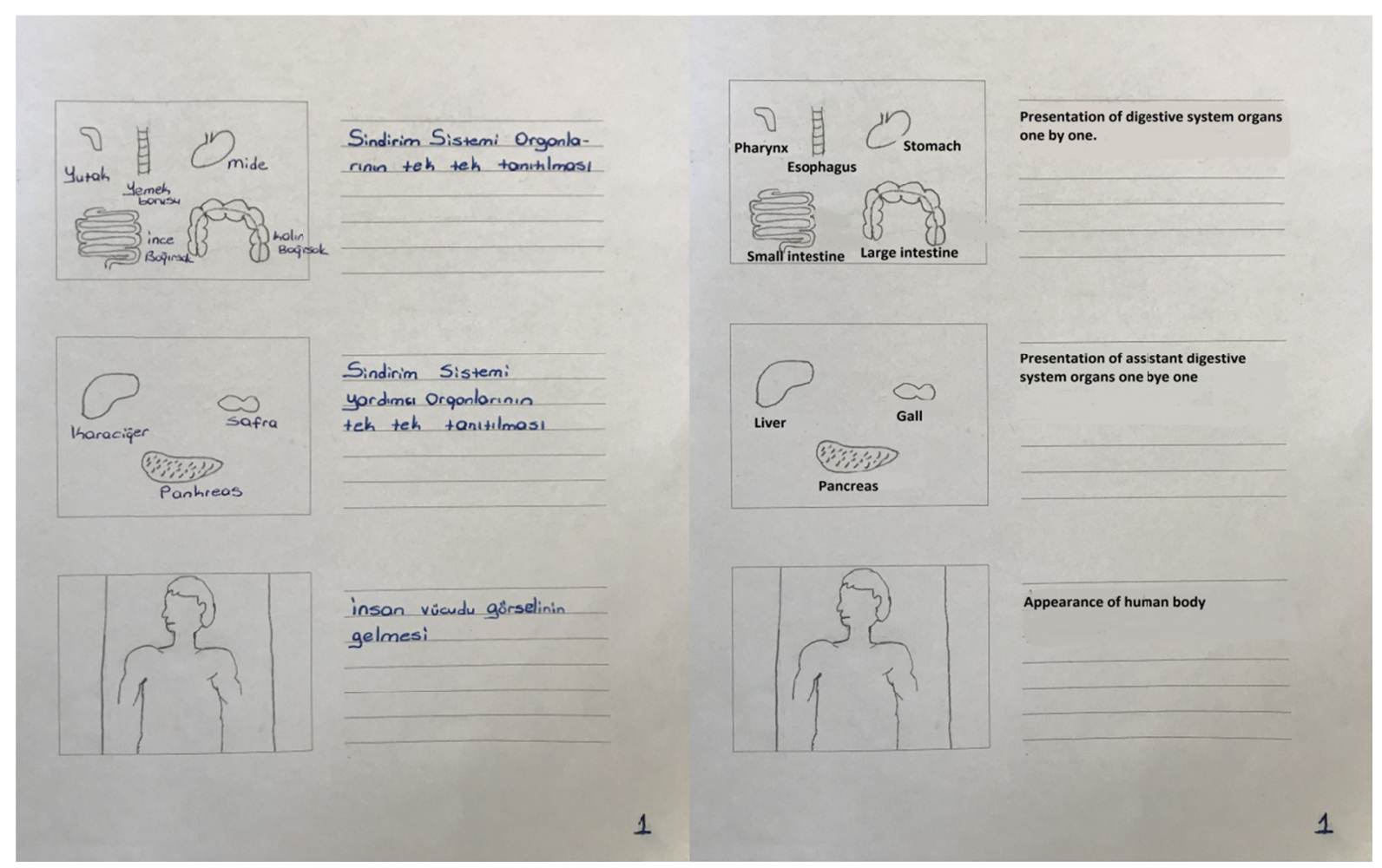

Figure 1. Storyboard of digestive system (Turkish and English)

Models: The preservice teachers formed 2D or 3D models using play dough, colored papers, cardboards or crayons based on the scenarios and drawings they had formed in their storyboards. 


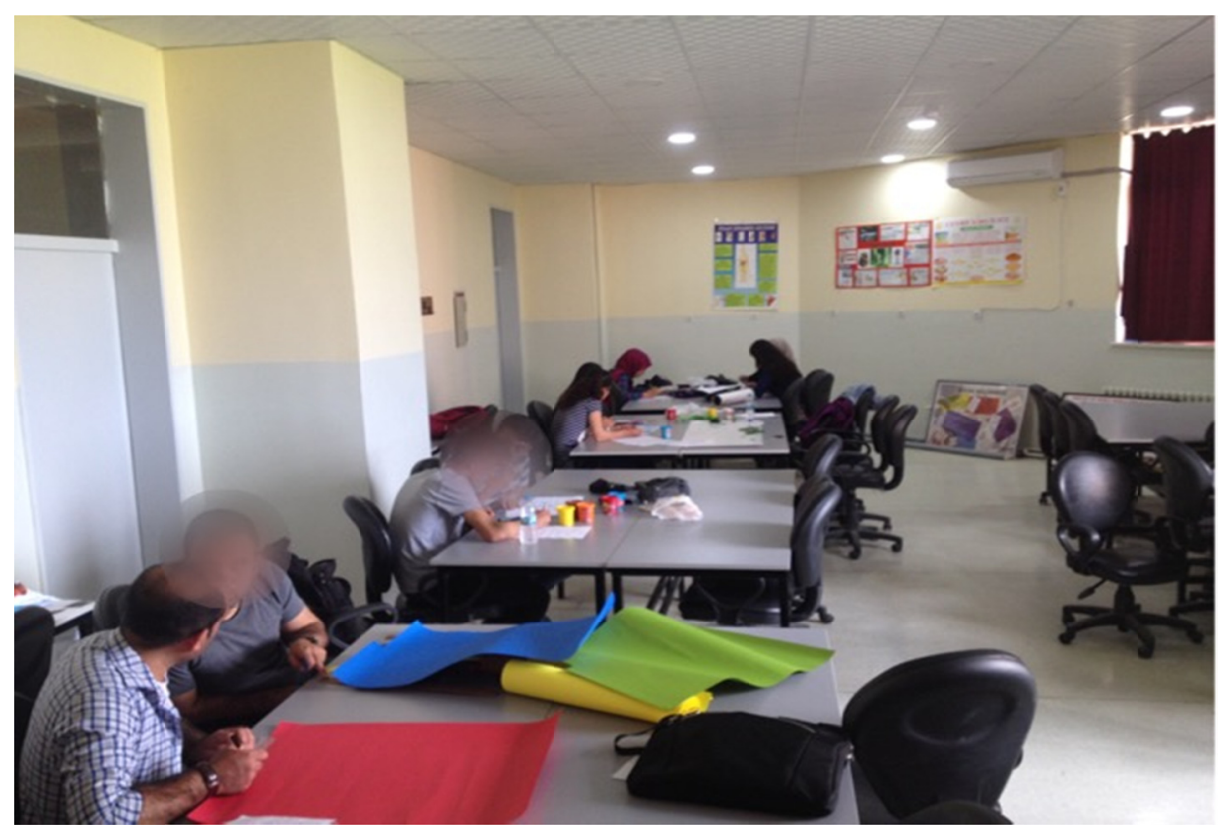

Figure 2. Application process

Digital photos: In this phase, the preservice teachers moved the models slowly and step by step which they formed with play dough and with other materials and took photos of these models.

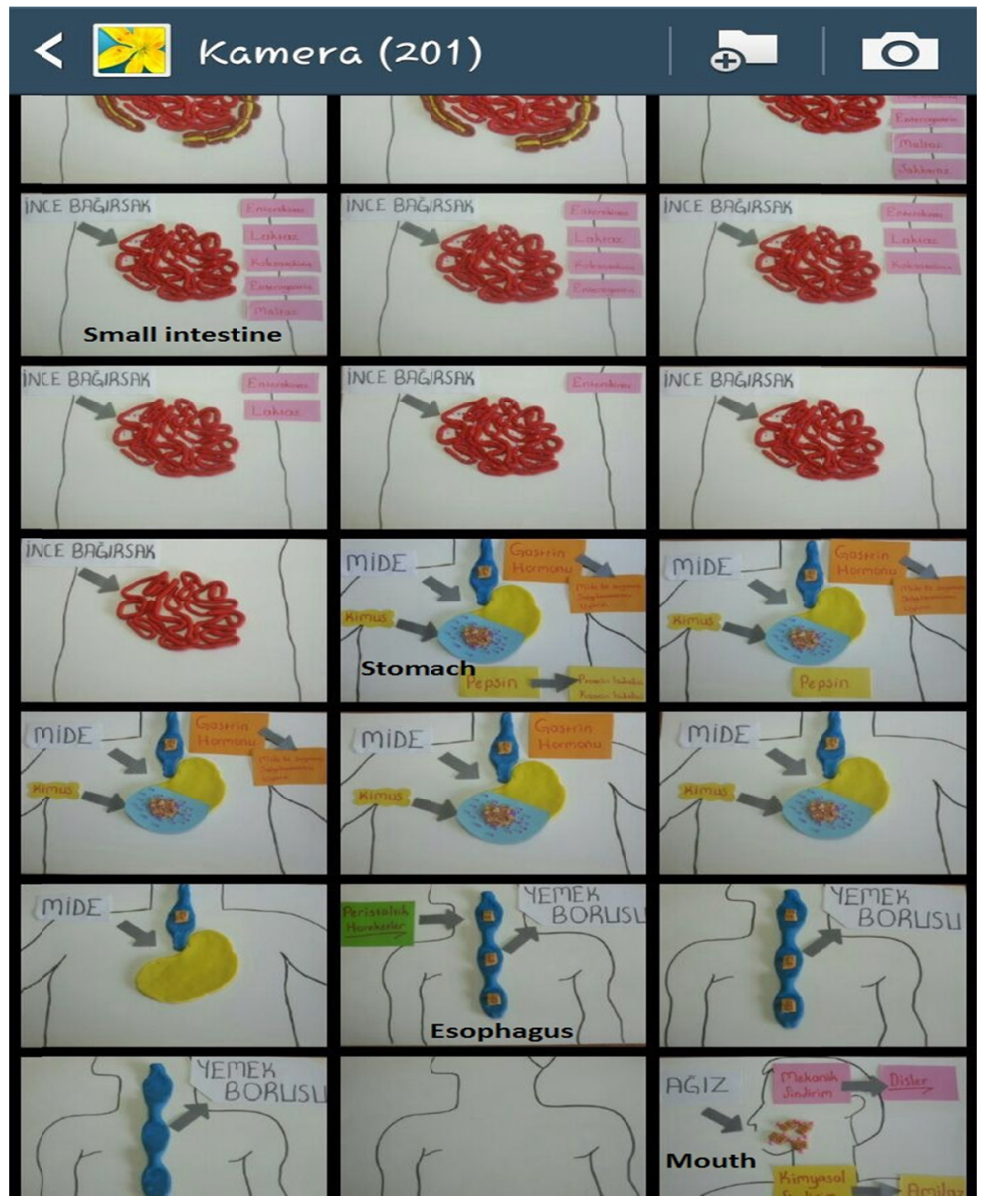

Figure 3. Digital photos about digestive system 
Animation: In the last phase, the photos taken were transferred to a mobile video-editing software program. The photos transferred to the software were put in order just in the way they were designed in the storyboard, and following this, other multimedia elements were included in the software. Some of the preservice teachers added music appropriate to their animations, while some of them vocalized their scenarios. Lastly, the video-editing software was set in a way to take two photos in a second, and the animation was finalized. The process of creating animations took 6-8 hours on average.

\subsection{Data Analysis}

The qualitative data collected via observations and semi-structured interviews in the study were analyzed using the content analysis method. Content analysis gathers similar data in themes and concepts and allows readers to understand the data more easily (Yıldırım \& Şimşek, 2013). The data collected from the preservice biology teachers via the interviews and observations were analyzed and interpreted using the software of Nvivo 11.0.

\section{Findings}

\subsection{Slowmation Subjects}

At the end of the application process, it was found that the slowmation subjects determined by the preservice teachers were the passage of substances through the cell membrane, digestive system, protein synthesis, phagocytosis, enzyme inhibitors and fertilization in flowered plants.

\subsection{1 st Century Skills and Other Positive Aspects}

Positive aspects about the slowmation process were examined under two themes: 21 st century skills and other positive aspects. Table 1 presents these themes.

Table 1. Influence of use of slowmation on some of the development of 21 st century skills and other positive aspects

\begin{tabular}{ll}
\hline 21st century skills & $\mathrm{f}$ \\
\hline Research skills & 3 \\
Information literacy skills & 2 \\
Communication and cooperation skills & 6 \\
Media literacy skills & 2 \\
Technology skills & 3 \\
Creativity & 5 \\
\hline Other positive aspects & 5 \\
\hline Entertaining & 2 \\
Raising awareness & 3 \\
Supporting multimedia & 2 \\
Drawing students' attention & 2 \\
Effective in teaching subjects & \\
\hline
\end{tabular}

As can be seen in Table 1, the preservice biology teachers thought that the process of creating slowmation contributed to some of the development of 21 st century skills. These skills were gathered under the themes of technology skills, information literacy skills, media literacy skills and creativity.

According to most of the preservice teachers, the slowmation activities contributed to the development of their creativity. In relation to the contributions of the activities, some of the preservice teachers reported that they tried to deal with the subjects in different ways in the process of creating slowmation and that they put forward new ideas in the process. Therefore, they thought that the process developed their creativity;

"I really think that it contributed to all of us with respect to creativity. For example, we think about what enzyme should be like. We envisaged it in our minds and did related research. Within the framework of this research, we tried to find something related through our imagination. (A1)"

“... I think it developed our creativity. For example, we didn't know how to teach a subject that we had determined. Then, we started to think about new things all the time. We produced many ideas. I mean I can say it increased our creativity. (A2)"

The preservice teachers were in constant communication with their group mates and with those in other groups in the process of activity development and that they all shared their ideas. At the end of the activity, the preservice 
teachers reported that the process contributed to their communication and cooperation skills. Some of the preservice teachers thought these activities would make it possible to increase teacher-student communication, while one of the preservice teachers put emphasis on group work stating that, while carrying out the slowmation activities, s/he wanted to gather students who did not get along well at all. The preservice teachers' related views were as follows:

"First of all, our communication skills developed a lot both with our group mates and with all our other friends because we were in constant traffic of information exchange. We spent more time with our friends, and it became more entertaining after a while. Therefore, it was an activity that developed our communication skills a lot. It was also true for our cooperation skills because for example, while I was preparing the play dough, our friend prepared the environment in which we would take photos. We somehow complemented each other. This was the aspect that the activity developed most. (A2)"

“... I said to myself that if I use this slowmation in my lessons one day, it will not only increase my communication with my students but also make the lessons more entertaining. I think it is an application that increases teacher-student relationships. (A5)"

The preservice teachers stated that the activities they carried out while doing research on the subjects about which they determined and creating their slowmation scenarios contributed to their research skills as well as their information literacy skills. In addition, they thought that the software programs used to edit slowmation videos developed their technology skills and media literacy skills:

"To me, it developed my information literacy because I had to be much knowledgeable about a subject while presenting information about that subject with the help of a few simple words. (A4)"

"We had considerable problems with the photos. We searched a lot while determining which software program we could use better. We tried and used a number of software programs. Therefore, I think our media skills and technology literacy skills developed. (A4)"

In addition, as can be seen in Table 1, the preservice biology teachers reported other positive views about the process of creating and said it was a process which was entertaining, which raised awareness, which supported multimedia, which was effective in teaching subjects, and which drew the students' attention.

Some of the preservice teachers stated that slowmation was an entertaining activity and that they enjoyed the process. Some of the preservice teachers reported that they started using slowmation in their daily lives, while some of them thought they would carry out these activities with their teachers in their future professional lives. In relation to this, A6 and A4, two of the preservice teachers, said;

“... Also, I liked the application a lot, and I already use it in my daily life with my friends just for fun."

“... It was an entertaining process, and I never got bored. In the future, I will use it with my students because I think it will draw students' interest. It is an unusual application."

Some of the preservice teachers thought that slowmation activities were effective in teaching subjects as the slowmation application allowed using multimedia elements. In addition, some of the preservice teachers reported that the slowmation application raised their awareness, saying;

"Instead of drawing on the blackboard, I can use slowmation. It provides better visuality. What I like most about this application is that we can use music and visuals together. I liked this feature a lot. (A1)"

“... In fact, I can say I realized that I can teach a subject in a lot more different way with the help of different applications rather than just teaching that subject directly on theoretical basis. (A5)”"

\subsection{Limitations and Difficulties Experienced}

Table 2 presents the themes regarding the limitations of the application and the difficulties experienced.

Table 2. Themes regarding the limitations of the application and the difficulties experienced

\begin{tabular}{ll}
\hline Limitations and Difficulties & $\mathrm{f}$ \\
\hline Group work & 3 \\
Using the software & 4 \\
Developing materials & 3 \\
Creating scenario & 1 \\
\hline
\end{tabular}


As can be seen in Table 2, the preservice biology teachers experienced certain problems and encountered with several limitations in relation to using the software and developing materials, working in groups, and creating scenarios in the process of creating slowmation.

It was found that the preservice teachers experienced problems especially while using the video-editing software of "Stopmotion Studio". The fact that the software included only the basic video-editing features and that its other features were not free of charge caused the preservice teachers to experience problems in the process editing the videos and caused some of the preservice teachers to prefer to use other mobile video-editing software programs. In relation to this, two of the preservice teachers, $\mathrm{A} 1$ and $\mathrm{A} 3$ reported the problems they experienced as follows:

“... also, we had problems with the editing process. We created the scenario, but we had difficulty in the editing process. (A1)"

"I couldn't use the Stopmotion program at all. For example, I failed to add music to my own application. Thus, I downloaded another program. (A3)"

Some of the preservice teachers experienced several problems while doing group work. In relation to this, one of the preservice teachers stated that $\mathrm{s} / \mathrm{he}$ had to do most of the work alone, and another preservice teacher reported that $\mathrm{s} / \mathrm{he}$ had communication problems with his/her group mates as they were not close friends. In addition, one of the preservice teachers stated that they did not agree on certain issues with his/her group mates. A3, one of the preservice teachers, said:

"At first, I disagreed with my friend on the subject. Then, we agreed on a topic, but we couldn't do anything about it. We tried another topic. Then, we agreed on that topic and did something."

Some of the preservice teachers stated that they faced some problems depending on the type of the material used. One of the preservice teachers believed it was difficult to create a scenario, saying:

"For example, we used play dough, but it leaves a trace on the cardboard after a while. Thus, the play dough was not actually a good idea. Instead, we could have used cardboard. (A5)",

\subsection{Suggestions on Usage of Slowmotion in Biology Teaching}

Depending on the data obtained from the interviews, the preservice teachers suggest some biology subjects that are suitable for creating slowmation and some materials that can be used in this process. These recommendations are; DNA reactions (3), the passage of substances through the cell membrane, digestive system (2), fertilization in flowered plants (2), digestion system (2) and urinary system (1), reproductive system (1), cell organelles (1), protein synthesis (1), neural transmission (1), phagocytosis (1), seed germination (1) and mitotic division and meiosis (1). Also, the preservice teachers thought besides the materials they used in the slowmation process, they thought they would be able to create slowmation using matchsticks, garden plants and drawings.

Preservice teachers' other suggestions regarding the use of slowmation in biology teaching are presented in Table 3.

Table 3. Themes regarding the use of slowmation activities in biology teaching

\begin{tabular}{ll}
\hline Suggestions & $\mathrm{f}$ \\
\hline It can be used to summarize the subject & 1 \\
Students and teachers can work together & 2 \\
It can be used to ensure permanency & 2 \\
Different tools and softwares can be used & 1 \\
\hline
\end{tabular}

As can be seen in Table 3, the themes related to the preservice biology teachers' suggestions regarding the use of slowmation activities in biology teaching were as follows: "It can be used to summarize the subject", "Students and teachers can work together", "It can be used to ensure permanency" and "Different tools and softwares can be used".

Some of the preservice teachers pointed out that it would be better if the students and the teacher decided to work together, while one of the preservice teachers stated that the computer and different software programs could be used. In addition, the preservice teachers thought that slowmation activities could be used to increase permanency in learning biology subjects and to summarize the biology subjects:

"I would choose the subjects together with the students in line with their interests. The teacher should guide students and determine the subjects with them. (A2)" 
"I can use it in biology education because it allows teaching the whole subject. As I said before, for example, the digestive system is not actually a simple subject, but I can teach this subject to students via two or three minutes video. (A6)"

\section{Conclusion and Discussion}

At the end of the research process, the preservice teachers reported that the slowmation application process contributed to some of the development of the 21st century skills such as creativity, communication and cooperation skills, information literacy and research skills, and technology and media literacy skills.

The preservice teachers stated that in the application process, they tried teaching the subjects in different ways and that their creativity increased thanks to the new ideas they produced. In literature, there are several studies reporting similar results. In one study carried out by Atalay, Anagün, and Kumtepe (2016), the preservice teachers stated that their creativity developed in the slowmation application process. Koçoğlu and Köymen (2003) pointed out that the learning environments which the students participated in as hypermedia designers developed their creative thinking. In another study, Erol and Taş (2012) found a significant relationship between the frequencies of the students' use of information and communication technologies and their creativity.

The preservice teachers stated that they constantly communicated with their group mates in the application process, exchanged their ideas, worked cooperatively and developed their communication and cooperative skills. Similarly, Hoban and Nielsen (2012), in their study, claimed that the process of creating slowmation and the product presentation created an environment of social interaction for preservice teachers and thus developed their communication and cooperation skills. In addition, another study conducted by Brown, Murcia and Hackling (2013) revealed that in applications involving multifaceted use of the slowmation technique, students obeyed the rules of working cooperatively and developed their cooperation skills. Other studies carried out by Atalay (2015), Atalay, Anagün, and Kumtepe (2016), Uzun and Karaman (2015) put forward results supporting the findings obtained in the present study.

In the study, the preservice teachers searched the subjects for which they created slowmation, and they developed their scenarios. They believed that the activities they carried out contributed to their research and information literacy skills and that the activities carried out to edit photos and videos developed their technology and media literacy skills. Kidman, Keast and Cooper (2012), in their study, pointed out that the learners developed their information and technology skills in the process of creating the slowmation when they put forward a product using these skills. Brown (2011) reported that the slowmations created by the students contributed to their technology skills as well as to their learning the science subjects. In addition, the digital storytelling process, a multimedia learning and teaching tool like the slowmation, is thought to develop technology and media literacy skills (Dogan, 2012; Karakoyun, 2014; Robin, 2008; Sadik, 2008)

When the other positive views of the preservice biology teachers about the application process were examined, it was seen that they found the process entertaining and interesting and that they even started using the slowmation technique in their daily lives. In addition, according to the preservice teachers, supporting the images with multimedia tools like music and audio was a beneficial aspect of the process. Also, the preservice teachers reported that the technique raised their awareness of different ways of teaching the subjects. In one study carried out by Atalay (2015), it was seen that the students searched together in the slowmation application process and learned in a more entertaining manner while working in cooperation. In another study, Brown, Murcia and Hackling (2013) pointed out that in an environment in which the slowmation technique was used; the students had entertaining experience in science education. Hayes (2003) claimed that activities based on the process of creating a video constituted an entertaining learning environment. Similarly, in studies involving digital storytelling applications, the students found the process entertaining and interesting (Karakoyun \& Yapıc1, 2016; Wang \& Zhan, 2010).

When the preservice teachers' views about the limitations and the difficulties experienced in relation to the slowmation application process were examined, it was seen that they mostly faced problems with the mobile video-editing application and experienced disagreements with their group mates on issues like task distribution. Moreover, the preservice teachers believed that it was difficult to create scenarios and that they experienced problems with the materials used. Similarly, in one study, Atalay (2015) reported that the students used and developed their communication skills in the slowmation application process and that they sometimes experienced difficulties in the subsequent phases of the application process in terms of work division. According to Dağ and Durdu (2011), although the communication within the group was quite good during the group works, there were problems with the sharing and execution of the tasks.

At the end of the application process, it was found that the preservice teachers created slowmation regarding biology subjects such as the passage of substances through the cell membrane, digestive system, protein synthesis, 
phagocytosis, enzyme inhibitors and fertilization in flowered plants. In addition, the preservice teachers found the following subjects appropriate to slowmation activities: DNA reactions, urinary and reproductive systems, cell organelles, neural transmission and mitotic division and meiosis. It was seen that while developing a model, mostly materials such as play dough, card board and crayons were used. The preservice teachers also reported that besides the materials they used, slowmation could be created by drawing pictures as well as by using matchsticks, plants and sandglass.

In relation to the use of slowmation activities in biology teaching, the biology preservice teachers put forward the following suggestions: students and teachers could work together in the application process; activities could be carried out to summarize the subject and to increase permanency in learning; and different tools and softwares could be used.

In the light of the findings obtained in the present study, the following suggestions could be put forward:

- When the effects of the application on the 21 st century skills and its other positive effects are taken into account, applications like this could be used in today's learning environments.

- In the process of editing photos and videos, different mobile applications or computer programs could be used. For example; Imovie, Vivavideo.

- While developing the models, different materials like toy blocks could be used.

- Future research could focus on the cognitive and affective effects of the slowmation technique in high school biology lessons.

\section{References}

Anagün, Ş. S., Atalay, N., Kiliç, Z., \& Yaşar, S. (2016). Öğretmen adaylarına yönelik 21. yüzyıl becerileri yeterlilik algıları ölçeğinin geliştirilmesi: Geçerlik ve güvenirlik çalışması. Pamukkale Üniversitesi Ĕgitim Fakültesi Dergisi, 40, 160-175.

Atalay, N. (2015). Fen bilimleri dersinde ögrencilerin ögrenme ve yenilenme becerilerinin gelişiminde yavaş geçisli animasyon (slowmation) uygulaması (Unpublished doctoral dissertation). Anadolu Üniversitesi, Eskişehir.

Atalay, N., Anagün, S. S., \& Kumtepe, E. G. (2016). Evaluation of Technology Integration in Science Teaching with 21st Century Skills: A Slowmation Application. Bartin Üniversitesi Egitim Fakültesi Dergisi, 5(2), 405 .

Brown, J. (2011). The impact of student created slowmation on the teaching and learning of primary science (Unpublished master's thesis). University of Edith Cowan, Australia.

Brown, J., Murcia, K., \& Hackling, M. (2013). Slowmation: A multimodal strategy for engaging children with primary science. Teaching Science, 59(4), 14-20.

Çelik, E. (2007). Ortaöğretim coğrafya derslerinde bilgisayar destekli animasyon kullanımının öğrenci başarısına etkisi (Unpublished master's thesis). Marmara Üniversitesi Eğitim Bilimleri Enstitüsü, İstanbul.

CEO Forum on Education and Technology. (1997). School technology and readiness report: From pillars to progress. Washington, D. C.: CEO Forum.

Creswell, J. W. (2013). Qualitative inquiry and research design. Choosing among five approaches (3rd ed.). Thousand Oaks, CA: Sage

Dağ, F., \& Durdu, L. (2011). Öğretmen adaylarının proje tabanlı ögrenme sürecine yönelik görüşleri. Paper presented 5th International Computer \& Instructional Technologies Symposium. Full paper retrieved from http://web.firat.edu.tr/icits2011/papers/27754.pdf

Dogan, B. (2012). Educational Uses of Digital Storytelling in K-12: Research Results of Digital Storytelling Contest (DISTCO) 2012. P. Resta (Ed.), Proceedings of Society for Information Technology \& Teacher Education International Conference 2012 (pp. 1353-1362). Chesapeake, VA: AACE. Retrieved from http://www.editlib.org/p/39770

Ekici, E., \& Ekici, F. (2011). Fen eğitiminde bilişi̧m teknolojilerinden faydalanmanın yeni ve etkili bir yolu: "Yavaş geçişli animasyonlar". Elementary Education Online, 10(2), 1-9.

Ekici, E., \& Ekici, F. (2014). Prospective science teachers' self-assessments about the use of slowmation approach in teaching. European Journal of Social Sciences Education and Research, 1(1), 91-94. https://doi.org/10.26417/ejser.v1i1.p91-94 
Erol, O., \& Taş, S. (2012). MYO Öğrencilerinin bilgi ve iletişim teknolojilerini kullanma sıklıkları ile yaratıcılık algıları arasındaki ilişkinin incelenmesi. Mehmet Akif Ersoy Üniversitesi Sosyal Bilimler Enstitüsü Dergisi, 4(7), 82-104.

Genç, M. (2013). Animasyonla eğitimin öğretmen adaylarının biyoloji tutumuna etkisi. Batı Anadolu Eğitim Bilimleri Dergisi, 4(7), 47-61.

Hayes, M. T. (2003). The pleasure of movie making. Journal of Computing in Teacher Education, 19(3), 82-86.

Herrington, A., Herrington, J., Hoban, G., \& Reid, D., (2009), Transfer of Online Professional Learning to Teachers' Classroom Practice. Journal of Interactive Learning Research, 20(2), 189-213.

Hoban, G. (2005). From claymation to slowmation: A teaching procedure to develop students' science understandings. Teaching Science: Australian Science Teachers Journal, 51(2), 26-30.

Hoban, G. (2007). Using slowmation to engage preservice elementary teachers in understanding science content knowledge. Contemporary Issues in Technology and Teacher Education, 7(2), 1-9.

Hoban, G. (2009). Facilitating learner-generated animations with slowmation. In L. Lockyer, S. Bennett, S. Agostino, \& B. Harper (Eds.), Handbook of research on learning design and learning objects: issues, applications, and technologies (pp. 313-330). Hershey, PA: IGI Global. https://doi.org/10.4018/978-1-59904-861-1.ch015

Hoban, G., \& Ferry, B. (2006). Teaching science concepts in higher education classes with slow motion animation (slowmation). E-Learn 2006 World Conference on E Learning in Corporate, Government, Healthcare \& Higher Education. Chesapeake, VA, USA: Association for the Advancement of Computing in Education.

Hoban, G., \& Nielsen, W. (2010). The 5 Rs: A new teaching approach to encourage slowmations (studentgenerated animations) of science concepts. Teaching Science, 56(3), 33-37.

Hoban, G., \& Nielsen, W. (2012). Learning science through creating a 'Slowmation': A case study of preservice primary teachers. International Journal of Science Education, 1-28.

Hoban, G., McDonald, D. C., Ferry, B., \& Hoban, S. (2009). Simplifying animation with "slowmation" to encourage preservice teachers' science learning and teaching. EDMEDIA World Conference on Educational Multimedia, Hypermedia and Telecommunications. Retrieved from http://ro.uow.edu.au/edupapers/108/

İnaç, A. E. (2010). Animasyon kullanımının ilköğretim öğrencilerinin Fen ve Teknoloji dersindeki akademik başarılarına ve akılda tutma düzeylerine etkisi: 6, 7 ve 8. sinuflar örneği (Unpublished master's thesis). Çanakkale Onsekiz Mart Üniversitesi Fen Bilimleri Enstitüsü, Çanakkale.

Karakoyun, F. (2014). Çevrimiçi ortamda oluşturulan dijital öyküleme etkinliklerine ilişkin öğretmen adayları ve ilköğretim ögrrencilerinin görüşlerinin incelenmesi (Unpublished doctoral dissertation). Anadolu Üniversitesi, Eskişehir.

Karakoyun, F., \& Yapıcı, İ. Ü. (2016). Use of Digital Storytelling in Biology Teaching. Universal Journal of Educational Research, 4(4), 895-903. https://doi.org/10.13189/ujer.2016.040427

Kidman, G., Keast, S., \& Cooper, R. (2012). Responding to the 5rs: An alternate perspective of slowmation. Teaching Science: The Journal of the Australian Science Teachers Association, 58(2), 24-30.

Koçoğlu, Ç., \& Köymen, Ü. (2003). Öğrencilerin hiperortam tasarımcısı olarak katıldığı öğrenme çevresinin yaratıcı düşünmeye etkisi. The Turkish Online Journal of Educational Technology, 2(3), 127-136.

Macdonald, D., \& Hoban, G. (2009). Developing science content knowledge though the creation of slowmations. The International Journal of Learning, 16(6), 319-330. https://doi.org/10.18848/1447-9494/CGP/v16i06/46366

Ochsner, K. (2010). Lights, camera, action research: the effects of didactic digital movie making on students' twenty-first century learning skills and science content in the middle school classroom (Unpublished doctoral dissertation). University of Arizona State, Arizona.

Paige, J. (2009). The 21st century skills movement. Educational Leadership, 9(67), 11.

Partnership for 21 st Century Learning. (2009). Framework for 21st century learning. Retrieved from http://www.p21.org/our-work/p21-framework

Robin, B. (2008). Digital storytelling: A powerful technology tool for the 21 st century classroom. Theory into 
Practice, 47, 220-228. https://doi.org/10.1080/00405840802153916

Sadik, A. (2008). Digital storytelling: A meaningful technology-integrated approach for engaged student learning. Educational Technology Research and Development, 56, 487-506. https://doi.org/10.1007/s11423-008-9091-8

Sanger, J. M., Brecheisen, M. D., \& Hynek, M. B. (2001). Can computer animations affect college biology students' conceptions about diffusion \& osmosis? The American Biology Teacher, 63(2), 104-110. https://doi.org/10.2307/4451051

Sezgin, M. E. (2002). İkili kodlama kuramına dayalı olarak hazırlanan multimedya ders yazılımının Fen Bilgisi ögretimindeki akademik başarlya, ögrenme düzeylerine ve kalıcllı̆̆a etkisi (Unpublished master's thesis). Çukurova Üniversitesi, Adana.

Uzun, E., \& Karaman, İ. (2015). Slow motion animasyon tekniği ile fotoelektrik olay konusunun modellenmesi ve öğrenci görüşleri. KSU Journal of Social Sciences, 12(2), 211-225.

Vratulis, V., Clarke, T., Hoban, G., \& Erickson, G. (2011). Additive and disruptive pedagogies: The use of slowmation as an example of digital technology implementation. Teaching and Teacher Education, 27(8), 1179-1188. https://doi.org/10.1016/j.tate.2011.06.004

Wang, S., \& Zhan, H. (2010). Enhancing teaching and learning with digital storytelling. International Journal of Information and Communication Technology Education (IJICTE), 6(2), 76-87. https://doi.org/10.4018/jicte.2010040107

Yakışan, M. (2008). Biyoloji ögretiminde bilgisayar animasyonlarının kullanılmasının ögrencilerin başarı, tutum ve kavram yanılgıları üzerine etkisi (hücre konusu örneği) (Unpublished master's thesis). Gazi Üniversitesi, Eğitim Bilimleri Enstitüsü, Ankara.

Yakışan, M., Yel, M., \& Mutlu, M. (2013). Biyoloji öğretiminde bilgisayar animasyonlarının kullanılmasına yönelik öğrenci görüşleri. Turkish Journal of Education, 2(3), 30-39. https://doi.org/10.19128/turje.181062

Yıldırım, A., \& Şimşek, H. (2013). Sosyal bilimlerde nitel araştırma yöntemleri. Ankara: Seçkin Yayınları.

\section{Copyrights}

Copyright for this article is retained by the author(s), with first publication rights granted to the journal.

This is an open-access article distributed under the terms and conditions of the Creative Commons Attribution license (http://creativecommons.org/licenses/by/4.0/). 